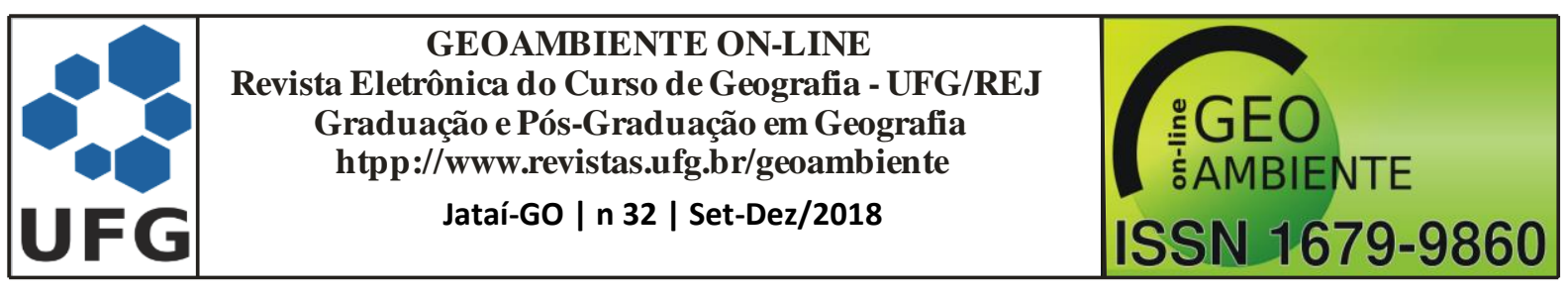

\title{
CLASSIFICAÇÃO DO USO E COBERTURA DA TERRA NAS BACIAS DOS RIOS MACACU E GUAPIAÇU ATRAVÉS DE INTERPRETAÇÃO DE IMAGEM LANDSAT 8 E ANALISE BASEADA EM OBJETOS
}

Vinicius da Silva Seabra ${ }^{1}$, Carla Bernadete Madureira Cruz $^{1}$, Rafael Cardão Augusto ${ }^{2}$ (1 - Universidade Federal do Rio de Janeiro - UFRJ, Docente - departamento de Geografia, email: vinigeobr@yahoo.com.br, carlamad@gmail.com, 2 - Universidade Federal do rio de Janeiro - UFRJ, Doutorando em Geografia, e-mail: rafaelcardao@hotmail.com).

Resumo: A classificação baseada em objetos coloca-se como uma importante metodologia de processamento digital de imagens de sensoriamento remoto, permitindo a obtenção de dados espaciais de forma rápida e precisa. O objetivo deste estudo é a elaboração do mapa de uso e cobertura da terra nas bacias dos rios Macacu e Guapiaçu, que são recortes espaciais estrategicamente importantes no estado do Rio de Janeiro, sendo realizado a partir de GEOBIA e imagem Landsat 8, sensor Operational Land Imager. Os resultados mostraram que esta metodologia de obtenção de dados espaciais resulta num esforço pequeno de edição (inferior a $3 \%$ da área total) com um nível de acertos superior a $85 \%$.

Palavras-chave: Classificação baseada em objetos, análise espacial, processamento digital de imagens de sensoriamento remoto

\section{LAND USE AND LAND COVER CLASSIFICATION IN THE WATERSHED OF RIVERS MACACU AND GUAPIAÇU BY INTERPRETATION OF LANDSAT 8 IMAGE AND OBJECT BASED ANALYSIS}

Abstract: The geographic object based image analysis is a relevant digital processing methodology applied in remote sensing data. This technology allows obtaining spatial data quickly and accurately. The objective of this study is to mapping of land use and land cover in the basins of Macacu and Guapiaçu rivers, which are strategic and important sites in the state of Rio de Janeiro, was made using GEOBIA and Landsat 8 image, from Operational Land Imager sensor. This paper showed that this method results in a lower cost editing (less than 3\% of total area) with a hit level exceeding $85 \%$.

\footnotetext{
Artigo recebido para publicação em 05 de Março de 2018

Artigo aprovado para publicação em 26 de Novembro de 2018
} 


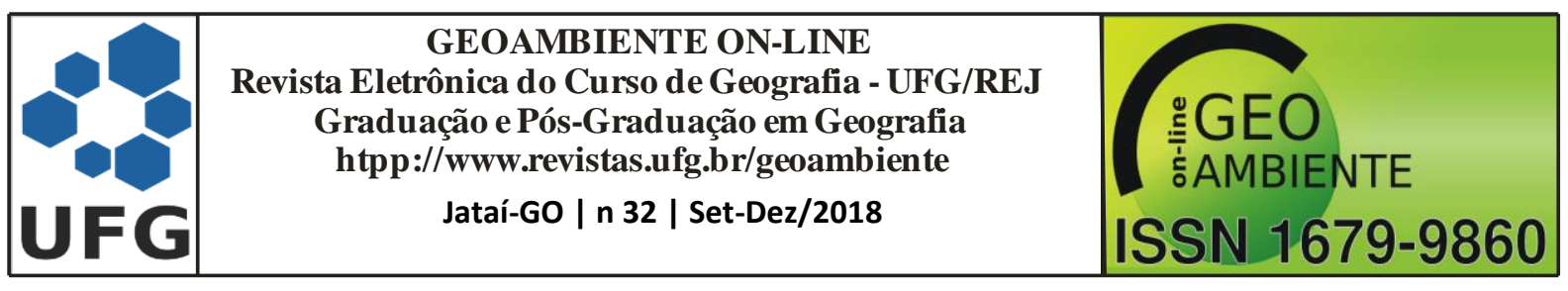

Keywords: Object-based classification, spatial analysis, digital processing of remote sensing images

\section{CLASIFICACIÓN DEL USO Y COBERTURA DE LA TIERRA EN LAS CUENCAS DE LOS RÍOS MACACU Y GUAPIAÇU POR INTERPRETACIÓN DE IMAGEN LANDSAT 8 Y ANÁLISIS BASADA EN EL OBJETO}

Resumen: La clasificación basada en el objeto se coloca como una importante metodología de procesamiento digital de imágenes de sensores remotos, lo que permite obtener datos espaciales con rapidez y precisión. El objetivo de este trabajo es la construcción del mapa de uso y cobertura de la tierra en las cuencas de los ríos Macacu y Guapiaçu, que son de importancia estratégica especial en el estado de Río de Janeiro, se realizando por GEOBIA y imagen Landsat 8, sensor Operational Land Imager. Los resultados mostraron que este método de obtención de datos necesita de poca edición (menos de 3\% del área total) y tiene un nivel de aciertos de $85 \%$.

Palabras clave: Clasificación baseada em objetos, análisis espacial, procesamiento digital de imágenes de teledetección

\section{INTRODUÇÃO}

A magnitude dos problemas ambientais e a busca pela solução dos mesmos ganharam uma amplitude global e passaram a despertar a atenção do mundo já a partir dos anos 80, quando então foram iniciadas as tentativas de elaboração de estratégias para o uso ordenado dos recursos naturais, planejando melhor a ocupação e uso da terra e buscando a recuperação de áreas degradadas.

Segundo Monteiro (1996), a amplitude da questão ambiental projeta-se multidisciplinarmente e requer uma integração interdisciplinar. A integração holística é um prérequisito necessário à compreensão da qualidade ambiental, ponto de partida para avaliações quantitativas e diagnósticos mais precisos possibilitando prognoses ambientais.

Neste cenário, as ciências espaciais não devem limitar-se apenas aos aspectos relacionados à localização precisa dos objetos geográficos e nem somente às técnicas estáticas e simplificadas de representação dos mesmos, mas também ocupar-se de compreender sua organização e complexidade nas diferentes estruturas, escalas e temporalidades. 


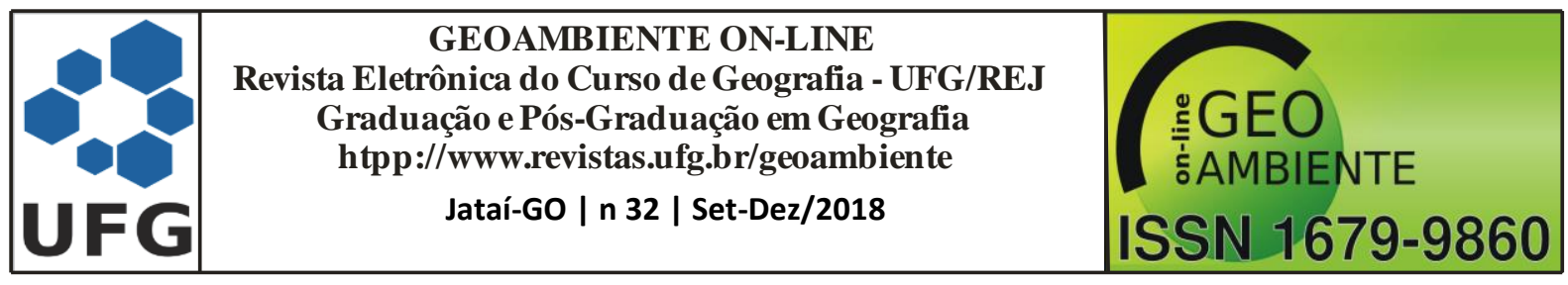

Da necessidade de discutir o ambiente a partir de uma perspectiva holística e integradora, ressurge a discussão da realidade a partir da concepção sistêmica, tendo o a Paisagem como conceito chave. Riábchicov (1976), por exemplo, aponta que a tarefa da Geografia é o estudo das paisagens naturais da superfície terrestre, considerando: suas leis zonais e condições geoestruturais de surgimento; seu desenvolvimento; sua ciclagem de substâncias e energia e; por fim, as intervenções do homem nesta paisagem (paisagem antroponatural). $\mathrm{O}$ autor aponta ainda que a diversidade de paisagens depende essencialmente das interações entre: calor e umidade; as peculiaridades das morfoestruturas e litologias do terreno; assim como a crescente influência do homem na paisagem. Significa afirmar que esta diversidade está estreitamente relacionada com a história de desenvolvimento da esfera geográfica em seu conjunto, e de suas distintas partes e componentes.

Desta maneira, os estudos relacionados aos problemas ambientais carecem de (Geo)informações precisas e atualizadas, criando demandas voltadas para a geração de levantamentos que contextualizem os objetos geográficos e tipologias da paisagem em suas complexidades e diferentes dimensões, ou seja, no espaço e tempo.

Para trabalharmos com esse grande conjunto de variáveis, em diferentes escalas e temporalidades, necessitamos de dados atualizados e precisos, além de metodologias capazes de facilitar as análises espaciais, armazenar e resgatar informações com velocidade e criar ambientes de saída para os resultados gerados.

Por isso, neste trabalho serão empregadas as técnicas e metodologias para aquisição e análise de dados disponibilizadas pelo geoprocessamento, sobretudo àquelas envolvidas com o processamento digital de imagens de sensoriamento remoto (PDI) e pelos sistemas de informações geográficas (SIG) para a geração de mapa de uso e cobertura da terra nas bacias dos rios Macacu e Guapiaçu, no estado do Rio de Janeiro.

As bacias dos rios Macacu e Guapiaçu (figura 1) limitam-se ao norte pela escarpa da Serra do Mar, onde encontramos as suas principais nascentes. Em suas porções leste e sudeste, esta bacia tem como limites formações montanhosas dos patamares residuais, também da Serra do Mar, e de maciços alcalinos do Tinguá e Rio Bonito. A confluência dos rios Macacu e Guapiaçu ocorre entre os municípios Cachoeiras de Macacu, Itaboraí e Guapimirim, e a partir daí toda a água drenada por estas bacias flui pelo Canal de Imunana, construído pelo extinto Departamento Nacional de Obras e Saneamento (DNOS), até chegar na Baía de Guanabara. 


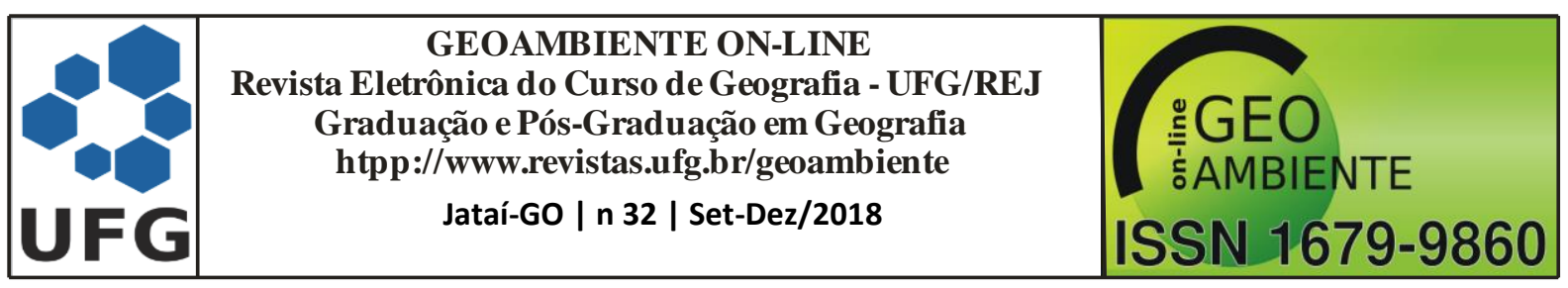

Figura 1. Localização das Bacias do Macacu e Guapiaçu
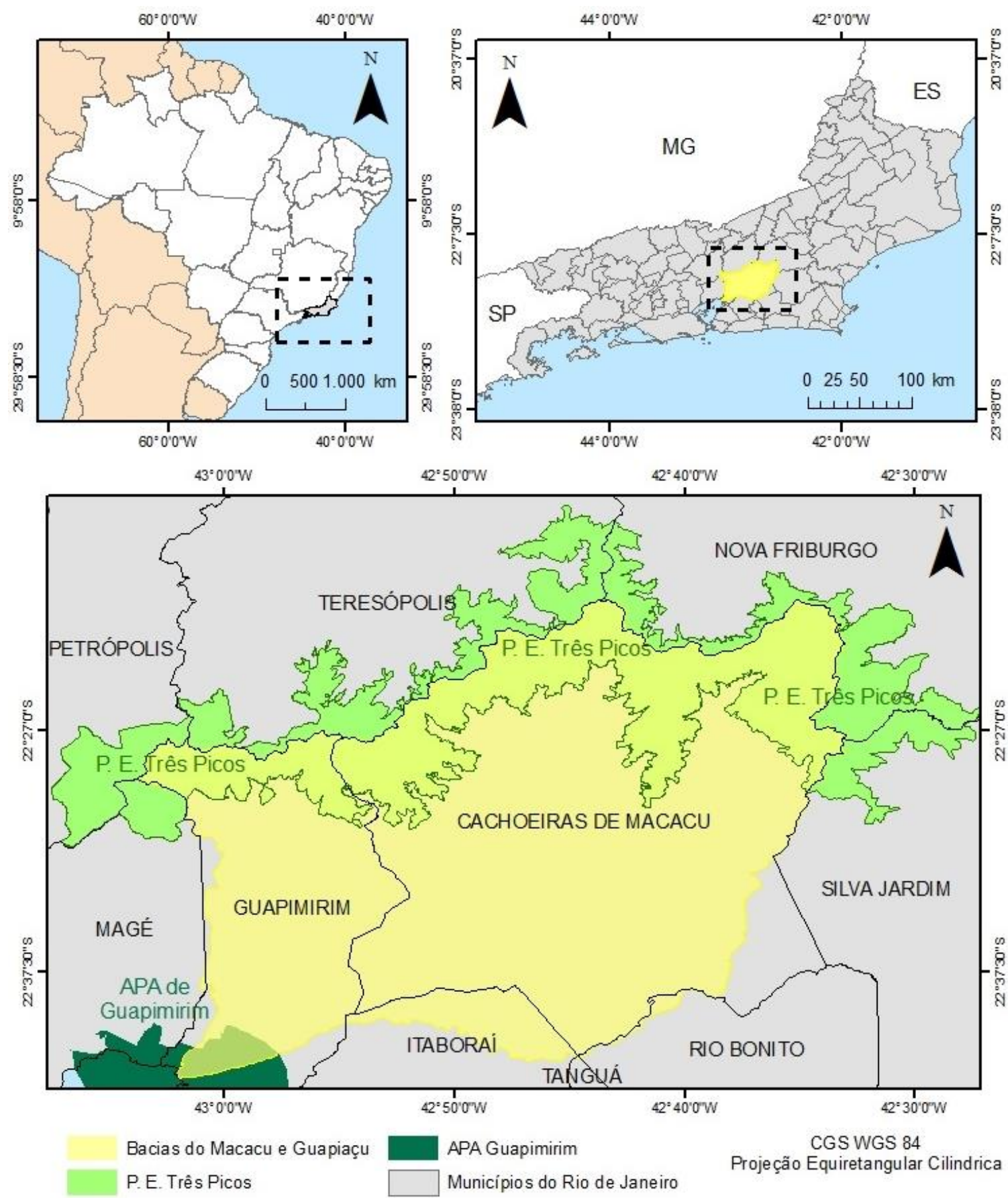

Organização: Autores

Estas bacias têm uma grande importância estratégica para o Estado do Rio de Janeiro, sobretudo para o leste metropolitano, uma vez que as suas águas abastecem grande parte da população da segunda maior metrópole do Brasil. Além de serem responsáveis pelo 


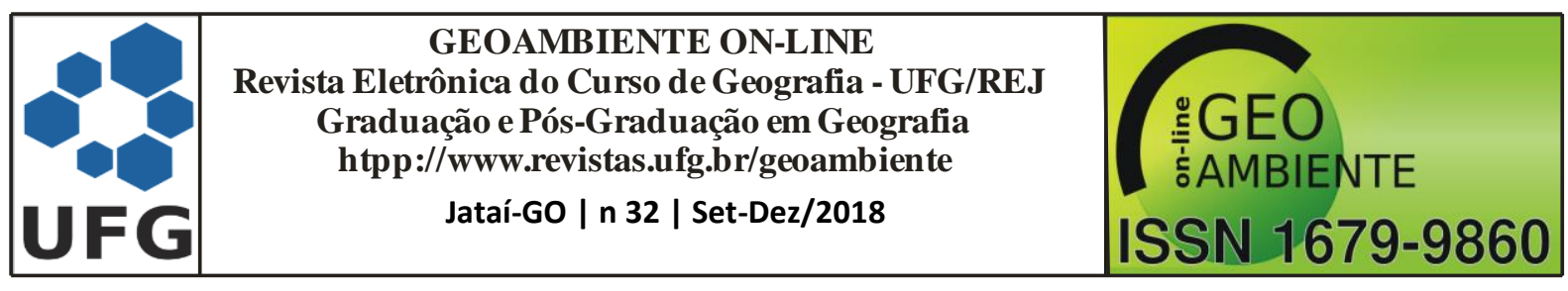

abastecimento de cerca de 2,5 milhões de habitantes nos municípios de Cachoeiras de Macacu, Guapimirim, Itaboraí, São Gonçalo e Niterói, tem-se ainda uma série de intervenções ocorrendo nas bacias dos rios Macacu e Guapiaçu, em virtude da construção do Complexo Petroquímico do Rio de Janeiro (COMPERJ) (figura 2).

Figura 2. Situação das Bacias do Rio Macacu e Guapiaçu

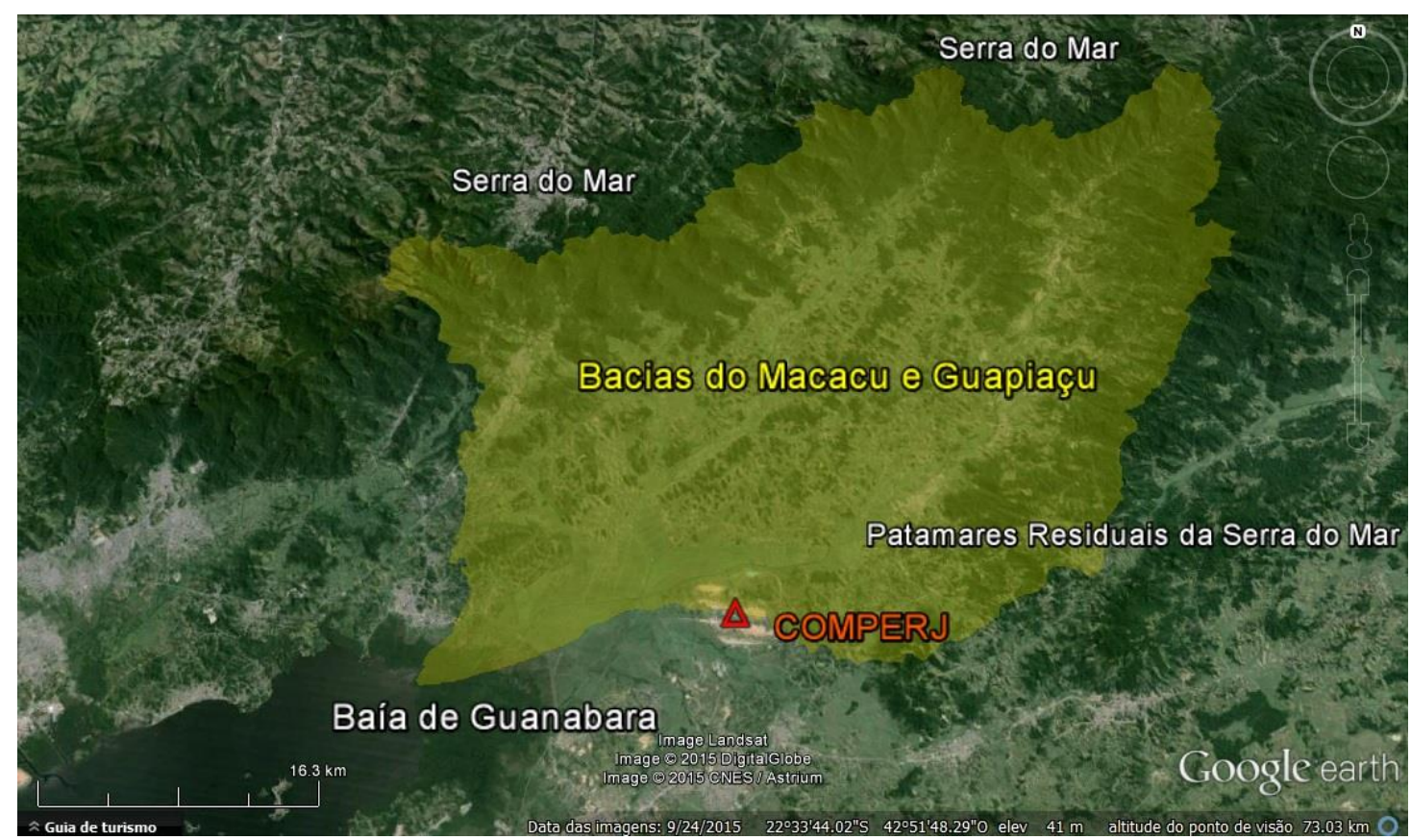

Organização: autores

Cabe ainda ressaltar a presença do Parque Estadual dos Três Picos, onde existem relevantes remanescentes de florestas ombrófilas densas, e da APA de Guapimirim, que abriga as mais importantes formações de manguezais da Baía de Guanabara, na metrópole do Rio de Janeiro. Estes fatores mostram a relevância das bacias em estudo no tocante à biodiversidade e preservação ambiental.

\section{CLASSIFICAÇÃO DE IMAGENS BASEADA EM OBJETOS}

Dentre as técnicas de PDI, a classificação de imagens configura-se como uma das mais importantes para a Geografia, sendo aplicada em grande parte das abordagens ambientais. Este processo está na origem da maioria dos mapas temáticos, dentre os quais temos os mapas de uso e cobertura da terra, mapas geomorfológicos, mapas de vegetação e outros. A classificação 


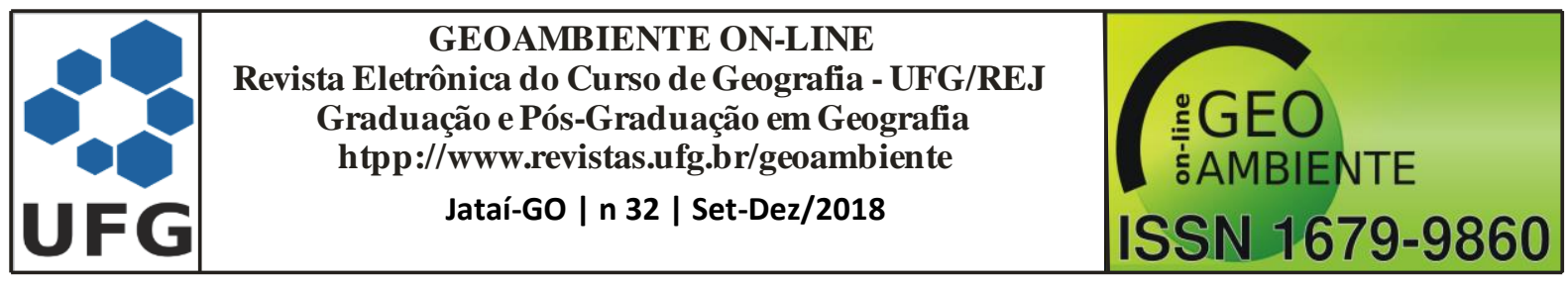

de imagens é embasada em alguma forma de interpretação de fotografias e/ou imagens, sejam provenientes de sensores passivos ou ativos. Esse processo pode ser totalmente visual, o que demanda muito tempo de execução e cuidados com a padronização/uniformização de critérios; automático, bastante questionado pela baixa acurácia dos resultados; ou ainda, semiautomático, que busca agregar vantagens dos dois processos anteriores, dando um espaço significativo para a etapa de edição manual (CRUZ et. al., 2009).

Em contraposição aos métodos de classificação tradicionais, a classificação de imagens baseada em objetos (GEOBIA) possibilita o uso de diferentes atributos dos objetos para sua diferenciação e interpretação, não se limitando às respostas espectrais dos alvos. Desta forma, passa a ser possível integrar, no processo de classificação, dados de outras origens (não só as imagens), determinar limiares fuzzy (não só booleanos), hierarquizar geometrias e itens de legenda, dentre outros. Segundo Blaschke (2010) a emergência da classificação baseada em objetos surge da necessidade da análise da paisagem através dos objetos espaciais, interpretados a partir das suas respostas espectrais, do seu contexto espacial e multiescalar e de dados temáticos terrestres (Earth Observation Data).

Neste processo, os polígonos construídos a partir da segmentação dão origem aos objetos da imagem, e as características espectrais relacionadas à forma e relações de vizinhança são as informações utilizadas na descrição destes objetos. A partir destes descritores, os objetos podem ser agrupados em categorias com significado ou em classes temáticas (DEFINIENS, 2010). Podemos então afirmar que o GEOBIA consegue se destacar diante dos tradicionais classificadores que tinham como base apenas os atributos espectrais e que não permitiam o uso de dados de diferentes tipos e resoluções.

Cruz et al. (2007) apontam que a classificação baseada em objetos geográficos busca simular técnicas de interpretação visual através da modelagem do conhecimento para identificação de feições, baseada na descrição de padrões identificadores, tais como textura, cor, métrica, contexto. A GEOBIA ainda se diferencia das demais técnicas por apresentar a possibilidade de se realizar multissegmentações, gerando níveis hierarquizados, incluindo ainda aspectos de multirresolução.

A modelagem do conhecimento, portanto, considera muitos tipos de descritores, tratando-os como parâmetros caracterizadores dos objetos, tais como: cor, textura, tamanho, forma, padrão, localização e contexto. Portanto, a inserção destes elementos, ou seja, do 


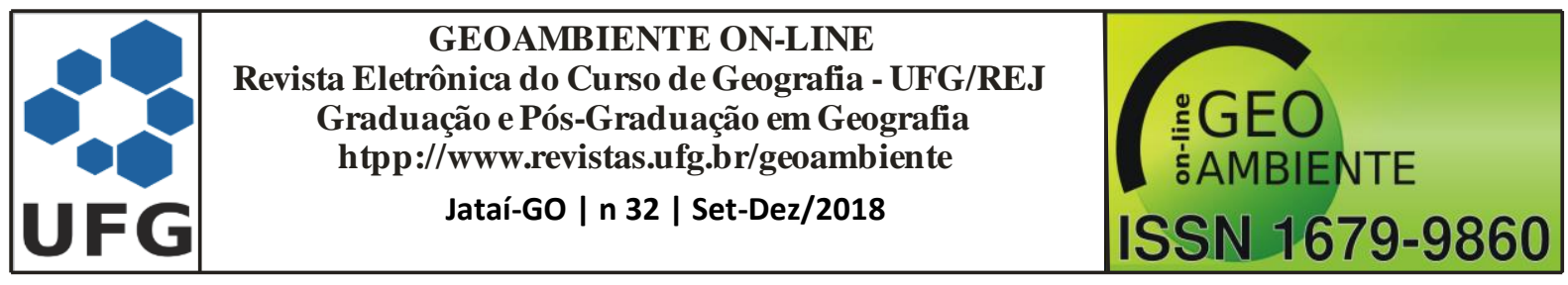

conhecimento do intérprete no processo, consiste em uma alternativa para a distinção de alvos que espectralmente apresentam dificuldades de serem mapeados. A caracterização dos objetos da imagem não pode limitar-se apenas a atributos espectrais, pois estes, muitas vezes, não conseguem delimitar objetos complexos (DEFINIENS, 2010).

\section{MATERIAL E MÉTODO}

A etapa inicial de classificação, e posterior análise de distribuição espacial, do uso e cobertura da terra nas bacias dos rios Macacu e Guapiaçu, passa pela aquisição da imagem orbital a ser utilizada neste processo. A escolha do dado condiciona-se diretamente à escala de mapeamento, e o rigor com que se espera classificar os objetos espaciais presentes na área de estudo. Sendo assim, a escolha da imagem a ser utilizada passa por suas resoluções espectral, radiométrica e espacial, além do tempo de revisita do sensor na área de interesse.

Pretende-se neste estudo elaborar representações e análises espaciais na escala cartográfica 1:100.000, numa abrangência regional, tendo como unidade espacial de análise as bacias dos rios Macacu e Guapiaçu, localizadas no leste do estado do Rio de Janeiro. Para atender tais objetivos, foi escolhida a imagem do sensor Operational Land Imager (OLI), transportado pelo satélite Landsat 8. Este dado foi adquirido, já ortorretificado, através do site Earthexplorer (http://earthexplorer.usgs.gov/) que é operacionalizado pelo Serviço Geológico dos Estados Unidos (USGS). A imagem foi obtida no dia 25 de setembro de 2015, e sua escolha baseou-se no fato de ser a cena mais recente sem cobertura de nuvens na área de interesse.

A imagem OLI conta com 9 bandas, sendo 8 delas multiespectrais (1-7,9) com resolução espacial de 30 metros, e uma banda pancromática (8) com resolução espacial de 15 metros. A resolução radiométrica destas cenas é de 12 bits (embora sejam disponibilizadas com 16 bits), e para este trabalho foram utilizadas as bandas 1 (azul costeiro), 2 (azul), 3 (verde), 4 (vermelho), 5 (infravermelho próximo), 6 (SWIR-1), 7 (SWIR-2) e a banda 8 (pancromática).

Para a correta utilização da imagem, foi necessária a realização da reprojeção da mesma para o sistema UTM WGS 84 23S, já que são disponibilizadas pela USGS com orientação para o hemisfério norte (UTM WGS 84 23N). Em seguida, as bandas de 1 a 8 foram importadas para o software Spring 5.3, para serem posteriormente exportadas em formato RAW, que é uma extensão compatível com o software 6S, onde foi realizada a correção atmosférica. 


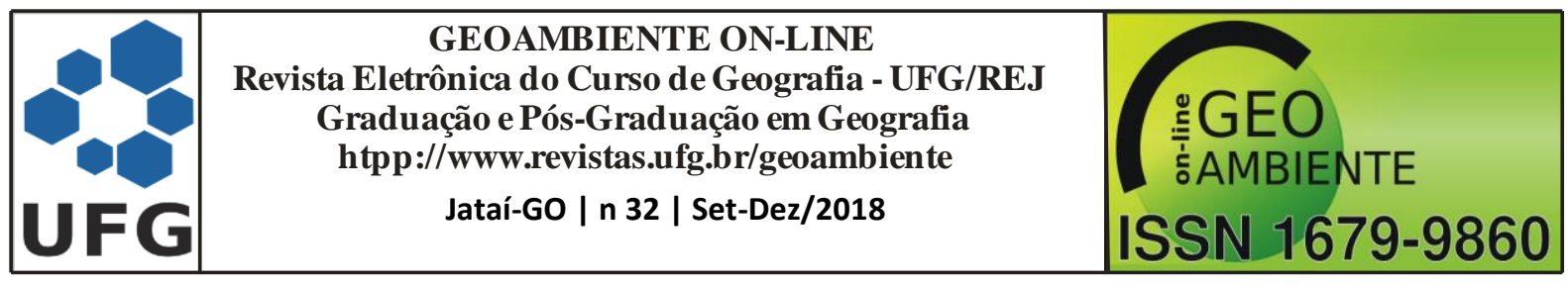

A correção atmosférica é fundamental uma vez que as interferências causadas por diferentes tipos de gases e partículas presentes na atmosfera alteram significativamente as repostas espectrais detectadas pelos sensores orbitais. Segundo Antunes et al. (2012) os efeitos diretos por conta da absorção e do espalhamento atmosférico produzem a alteração do brilho da cena e a diminuição de contraste entre os alvos, dificultando com isso a diferenciação e identificação dos mesmos.

A correção atmosférica realizada através do algoritmo $6 \mathrm{~S}$ utilizou os mesmos parâmetros testados e aplicados por Soares, et al. (2015) e Pimenta et al. (2013), já que se trata da mesma área e do período do ano em que estes estudos foram realizados. Sendo assim, os parâmetros escolhidos foram: modelo de atmosfera tropical, modelo de aerossóis urbano, parâmetro de visibilidade com $15 \mathrm{~km}$ (levando em conta características locais, época do ano e análise visual) e superfície média de $50 \mathrm{~m}$ acima do nível do mar. Outros parâmetros, tais como: data e horário de aquisição, número de linhas e colunas da imagem e informações sobre as bandas, foram adquiridos nos metadados da imagem.

Depois de minimizar as interferências da atmosfera, através da correção atmosférica no algoritmo 6S, as bandas foram recortadas para a área de interesse, no software ArcGIS 9.1. Em seguida, a cena foi incorporada ao projeto Definiens, onde também foram adicionados os demais dados temáticos, para a construção do projeto de classificação baseado em objetos. As etapas metodológicas estão detalhadas na figura 3.

Além dos descritores espectrais normalmente utilizados, provenientes das médias e desvios padrão das bandas do azul, verde, vermelho, infravermelho próximo, infravermelho médio e infravermelho distante, foram incorporados os índices NDVI, NDBI e BuildUp (ZHA et. al, 2003), o MDE Topodata (VALERIANO, 2005), além de dados temáticos de Geologia e Geomorfologia (figura 4).

A construção do mapa geológico partiu da vetorização das folhas geológicas disponibilizadas pelo Serviço Geológico do Rio de Janeiro (DRM-RJ) e de processos de edição necessários para adequação da litologia do terreno às bases e temas já existentes no BDG. A escala de levantamento dos dados originais é 1:50.000, no entanto, os dados vetoriais adquiridos respeitavam a escala de representação 1:400.000. Por isso os arquivos foram submetidos a correções topológicas para a retirada de (ruídos) e suavização de contornos. 


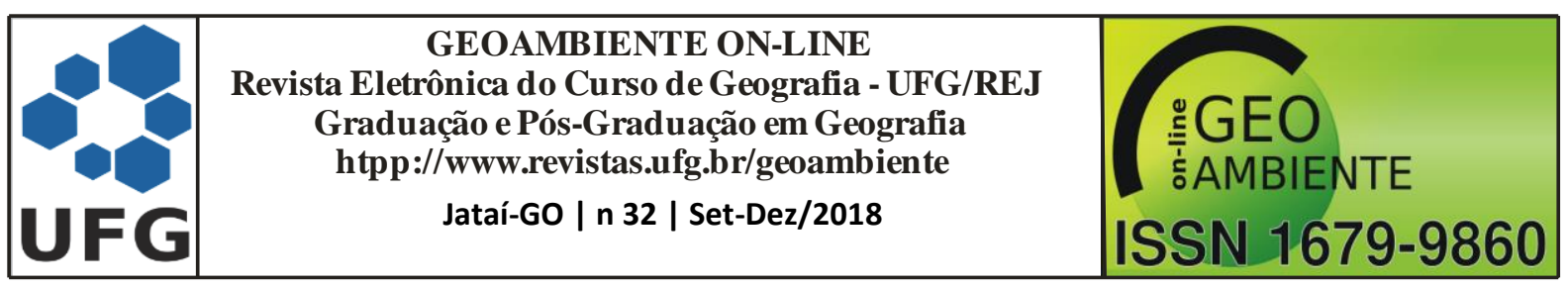

Figura 3. Fluxograma de Atividades

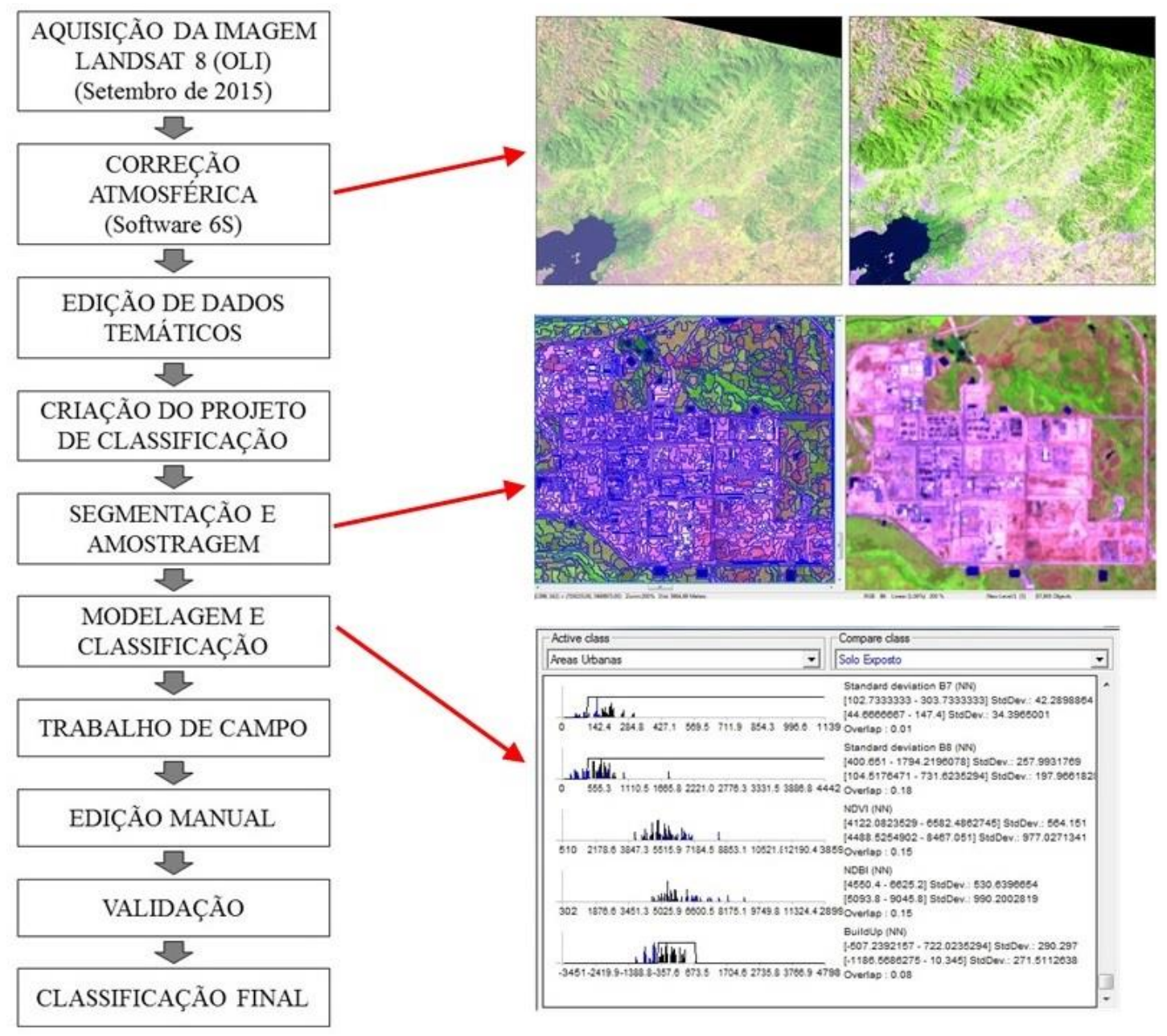




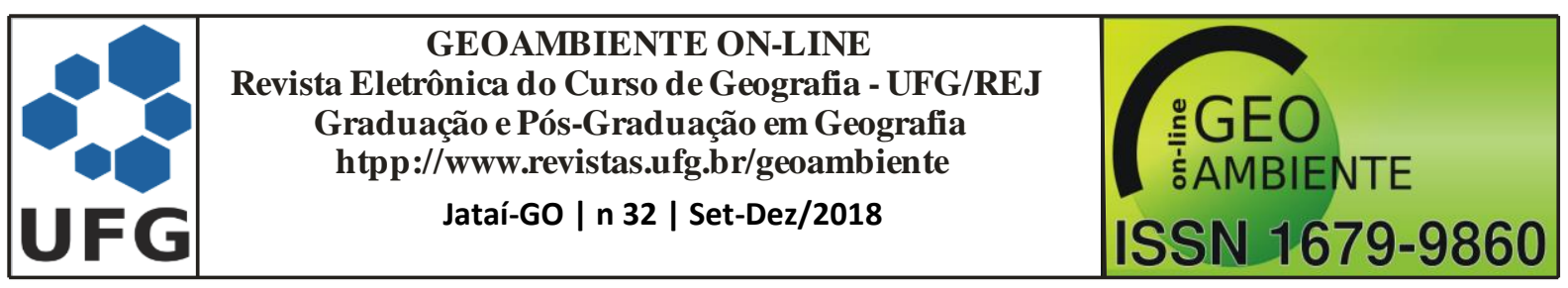

Figura 4. Classificação hierárquica e descritores utilizados na classificação

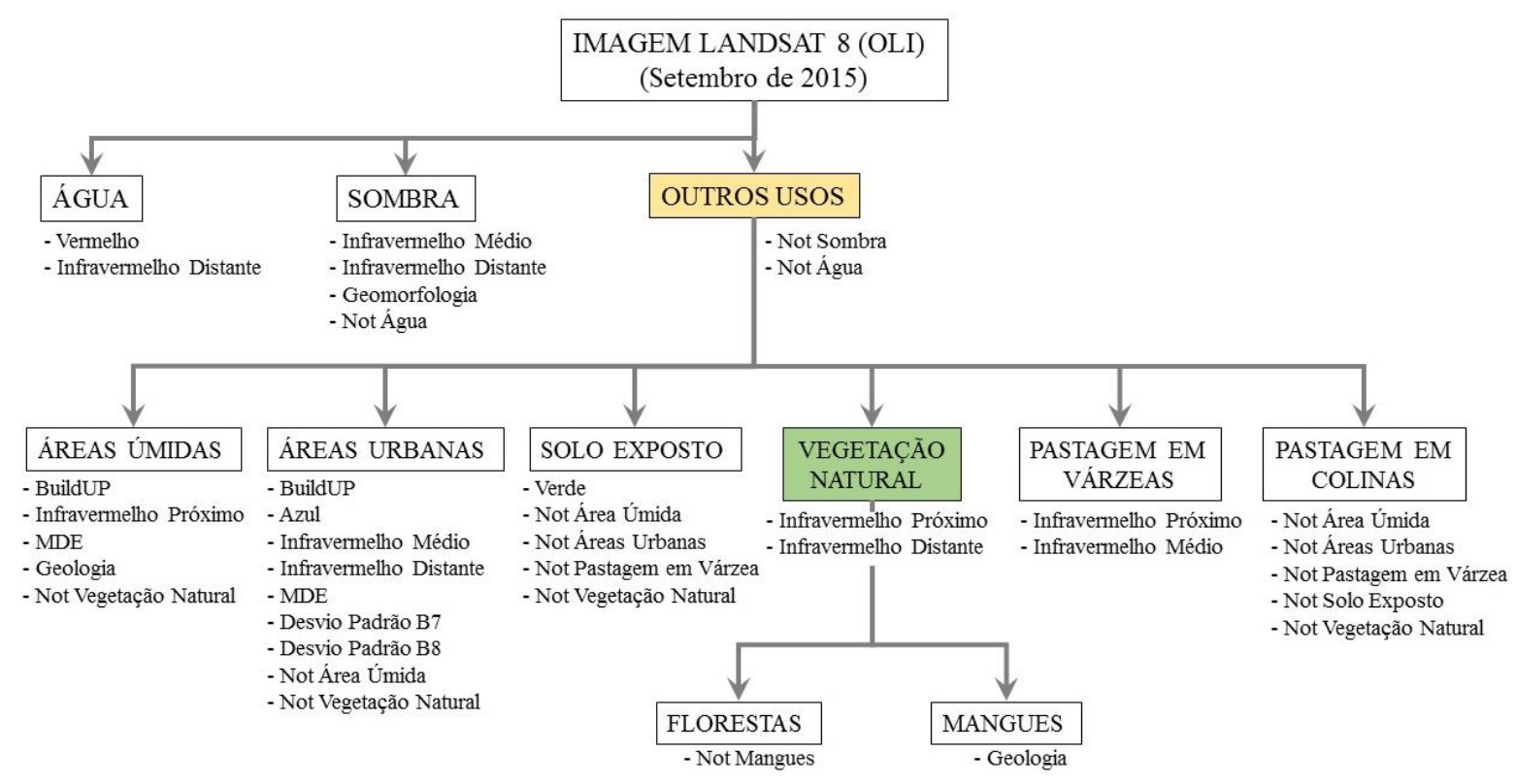

Ainda com a utilização do MDE Topodata e de dados topográficos do IBGE (1:50.000), foram traçados os limites das sub-bacias de terceira ordem das bacias e, em seguida, dos rios contribuintes para os rios principais. Para cada uma destas bacias foram calculados os respectivos níveis de base, que foram então definidos a partir da confluência de rios de $3^{\circ}$ ordem, ou da cota altimétrica da foz dos rios de menor ordem. Com estes limites hidrográficos e com os valores de altitude absoluta, tornou-se possível o cálculo do nível de base para cada sub-bacia e posteriormente o cálculo da amplitude do relevo em cada ponto. Com dados de amplitude do relevo e declividade, foi gerado então o mapa Geomorfológico (SEABRA, 2012).

A etapa de classificação se deu após a segmentação da imagem OLI, que foi executada com pesos iguais para cada banda espectral, com parâmetro de escala 50, forma 0,1 e compacidade 0,5 . O processo de classificação se deu em três níveis diferentes, onde no primeiro classificou-se a classe "Água”, a classe "Sombra" e "Outros Usos". No segundo nível, os "Outros Usos" foram reclassificados em Áreas Úmidas, Áreas Urbanas, Solo Exposto, Vegetação Natural, Pastagem em Várzeas e Pastagem em Colinas. Em seguida, a classe "Vegetação Natural" foi reclassificada em Florestas e Mangues, no que foi considerado o terceiro nível de classificação. Por fim, as classes Pastagem em Várzeas e Pastagem em Colinas foram generalizadas para uma única classe de uso e cobertura da terra, chamada de Pastagens. A modelagem da classificação e os descritores utilizados estão apresentados na figura 4. Em 


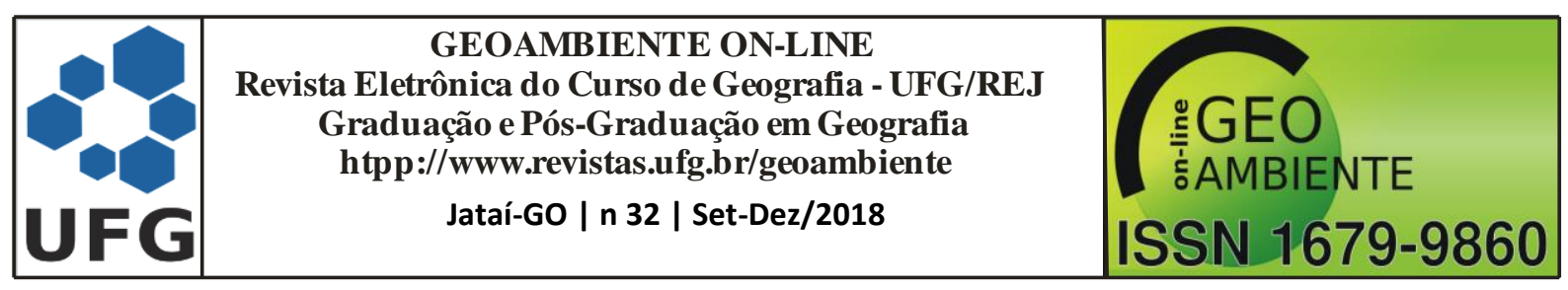

seguida, foram feitas edições manuais para o refinamento do mapa de uso e cobertura da terra, baseadas no conhecimento da área e em dados de trabalhos de campo (figura 5).

Figura 5. Áreas editadas na classificação da bacia dos rios Macacu e Guapiaçu

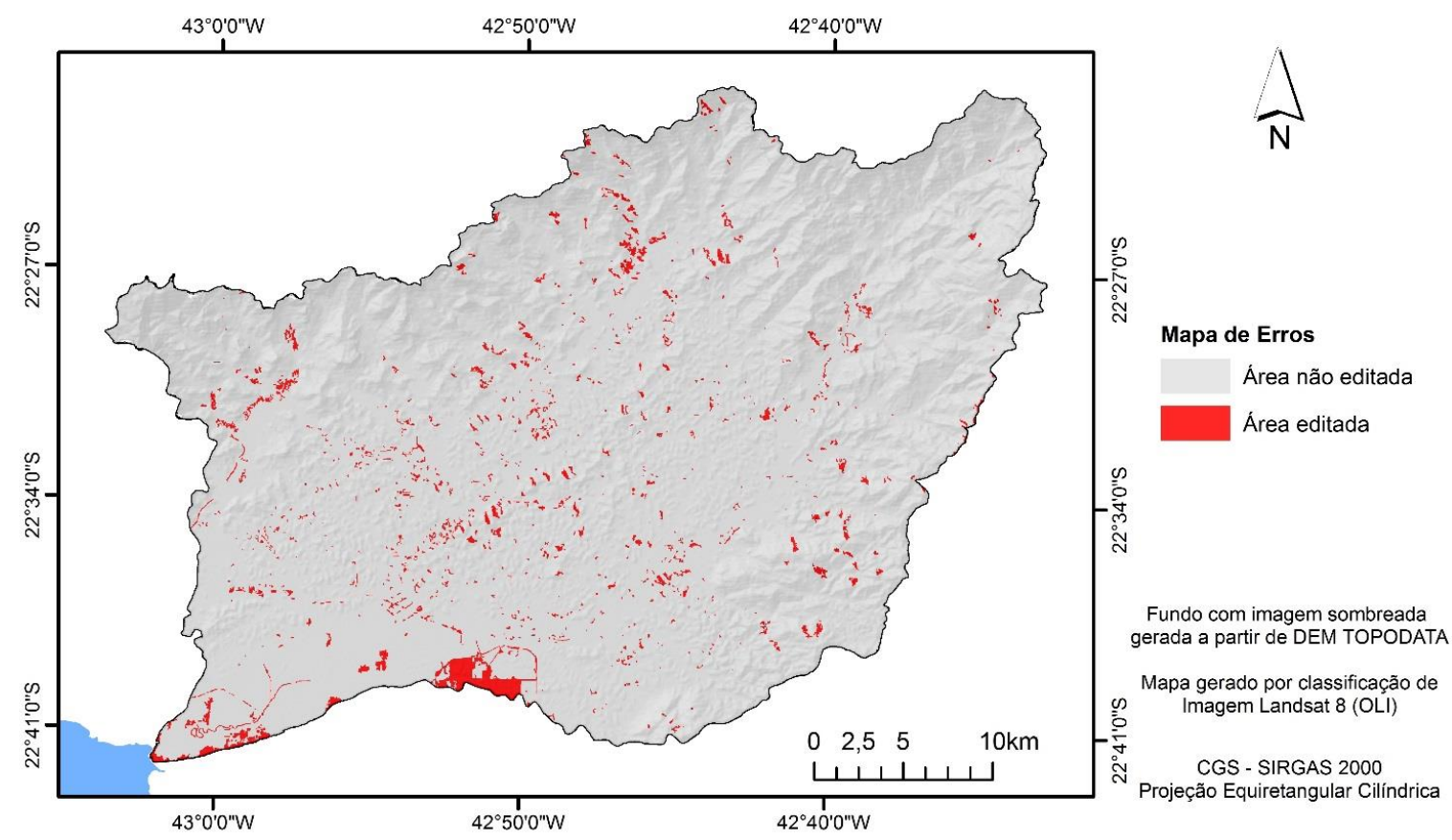

Por fim, a validação do mapa de uso e cobertura da terra das bacias dos rios Macacu e Guapiaçu se deu a partir de amostragem de $20 \%$ de todos os objetos classificados após todas as etapas do mapeamento, inclusive os de edição e generalização por dissolução. Para tal, todos os objetos foram separados por classes, e para cada um de seus polígonos representantes foram gerados centroides. Significa dizer que para cada classe do mapeamento de uso e cobertura da terra foram gerados, para todos seus objetos (polígonos), seus respectivos centroides (pontos), para uma posterior amostragem aleatória e estratificada (LANDIM, 2003).

Os pontos separados por classes foram submetidos à função Subsetting, do módulo Geostatistical Analyst, do software ArcGis 9.1, que executou a divisão de cada conjunto de pontos aleatoriamente em duas partes, como conjunto de pontos de treinamento e teste (figura 6). Estipulou-se a seleção de $20 \%$ de amostras por objetos de uso e cobertura da terra, perfazendo um total de 676 amostras. 


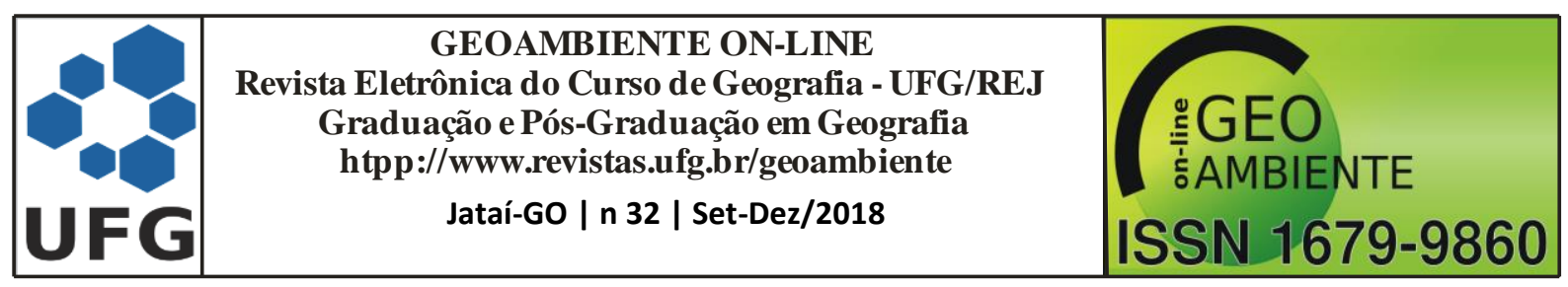

Figura 6. Seleção de amostras no Geostatistical Analyst

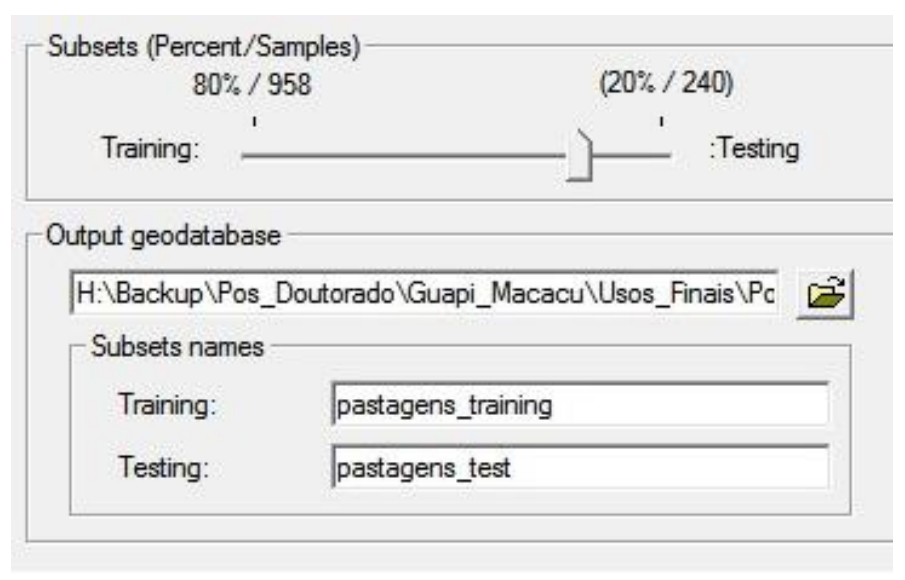

Todos os pontos amostrais selecionados foram exportados para a extensão KMZ, e verificados a partir no Google Earth (figura 7). Os pontos com usos compatíveis com o que fora determinado na classificação foram considerados acertos, e as incompatibilidades foram julgadas como erros. A distribuição espacial dos pontos amostrais por classes temáticas pode ser observada no mapa da figura 8 .

Figura 7. Processo de validação da classificação de uso e cobertura da terra

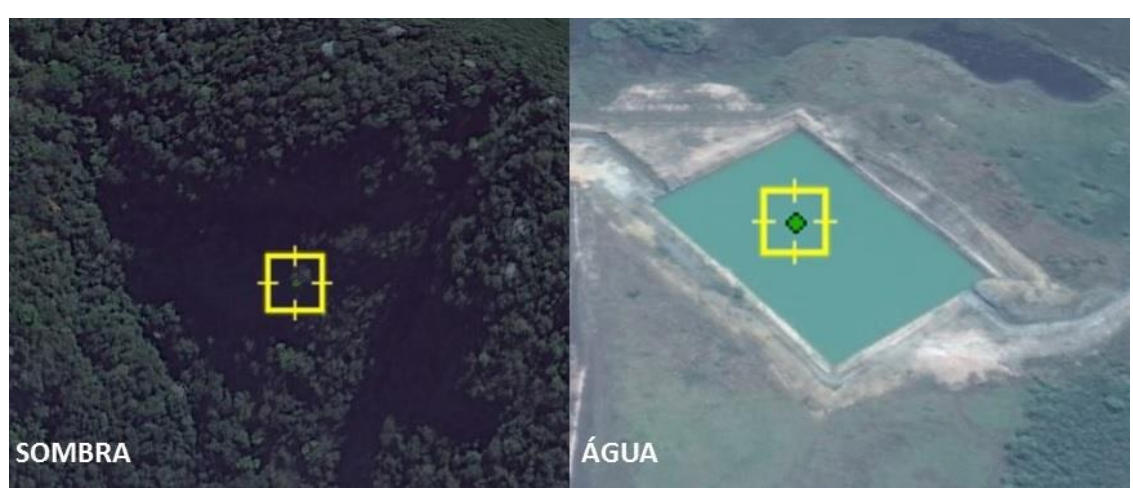




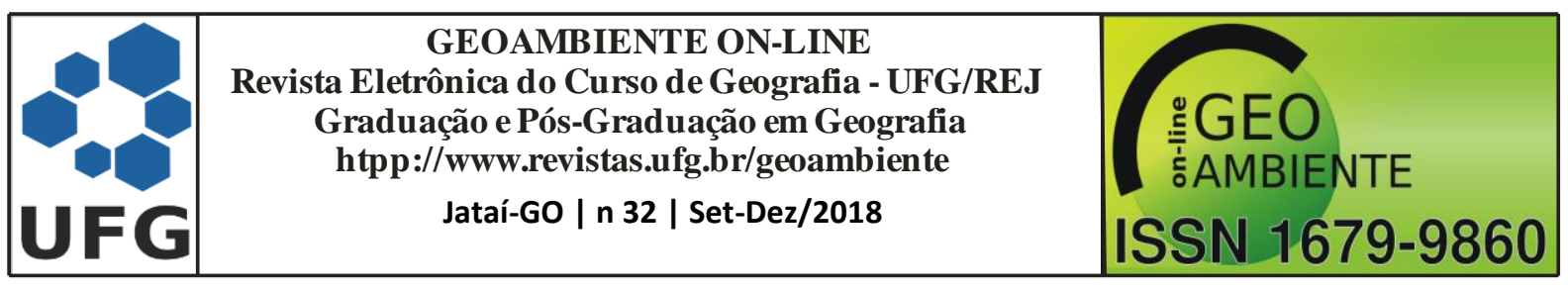

Figura 8. Distribuição dos pontos amostrais para validação da classificação de uso e cobertura da terra

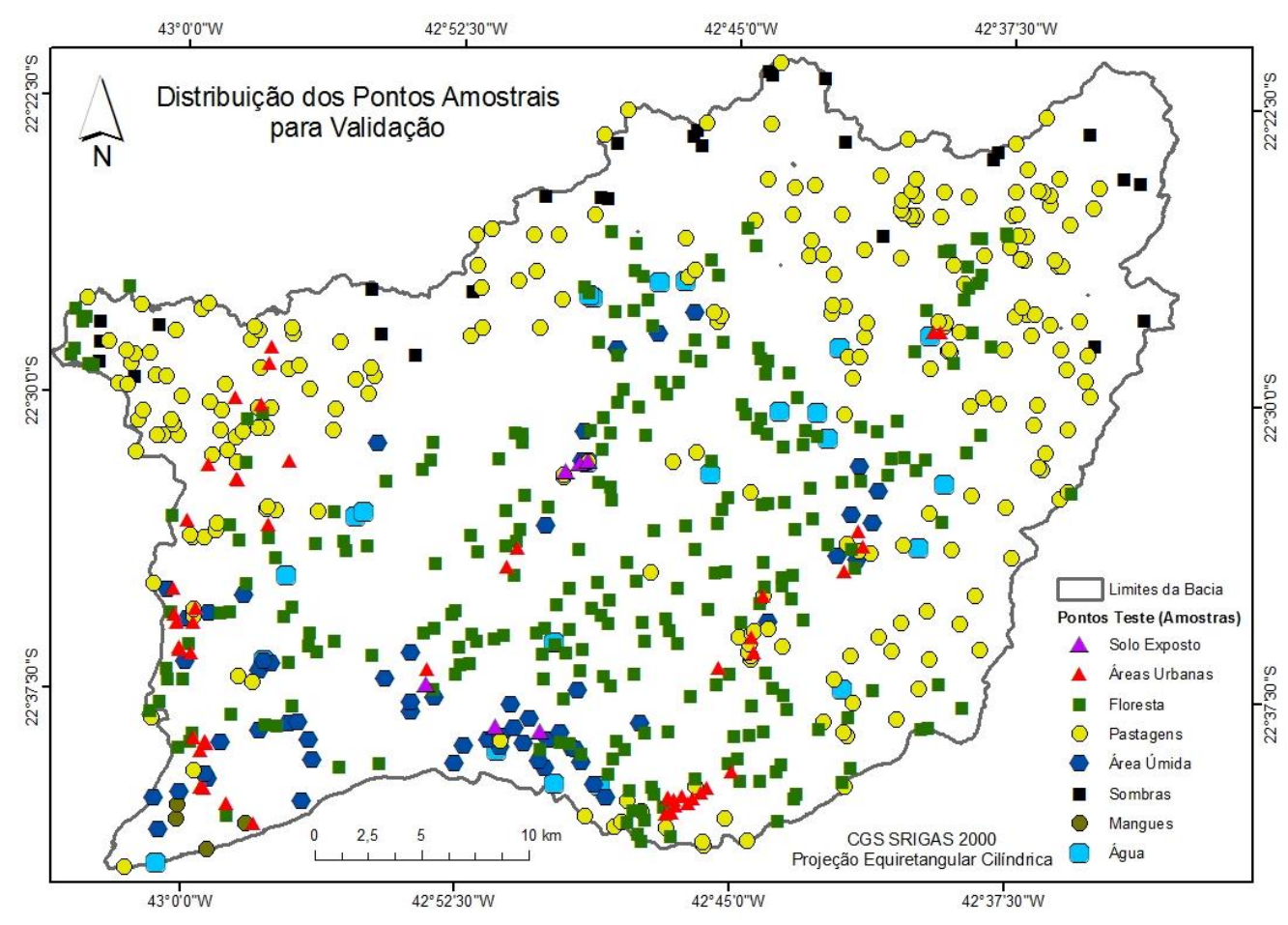

\section{RESULTADOS E DISCUSSÃO}

As edições manuais realizadas no mapa de uso e cobertura (figura 9), elaborado através de modelagem e classificação automática, restringiram-se apenas a 33,53 km² (quadro 1), o que representa apenas $2,65 \%$ da área mapeada $\left(1.266,89 \mathrm{~km}^{2}\right)$. Este aspecto deixa claro que o processo de classificação por modelagem do conhecimento baseada em objetos reduz em muito o esforço de edição, na medida em que aumenta a eficácia da classificação.

As edições apontam que a modelagem subestimou, ainda que bem pouco, a classe "Floresta" em detrimento da classe "Pastagem", já que a edição nesta direção representou $31,60 \%$ do esforço total de edição. É possível que boa parte desta confusão esteja relacionada ao limiar de separação entre pastos sujos e formações florestais em estágios iniciais (capoeiras). A edição de "Áreas urbanas" para "Pastagem” representou um esforço total de 21,42\%, o que também foi considerada significativa diante do total. Por fim, consideramos também significativo o esforço de edição de "Pastagem" para “Áreas urbanas", que somou um total de $10,61 \%$ de toda edição realizada nas bacias. 


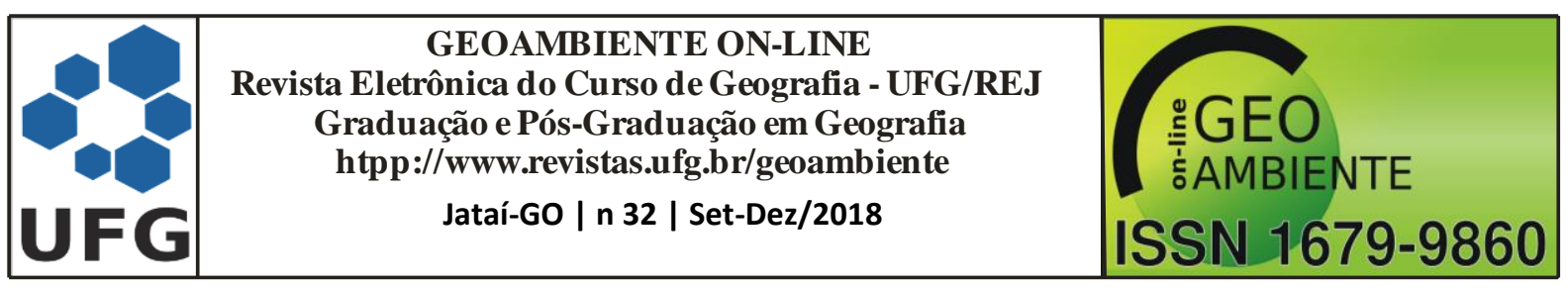

Figura 9. Classificação não editada e editada das bacias dos rios Macacu e Guapiaçu

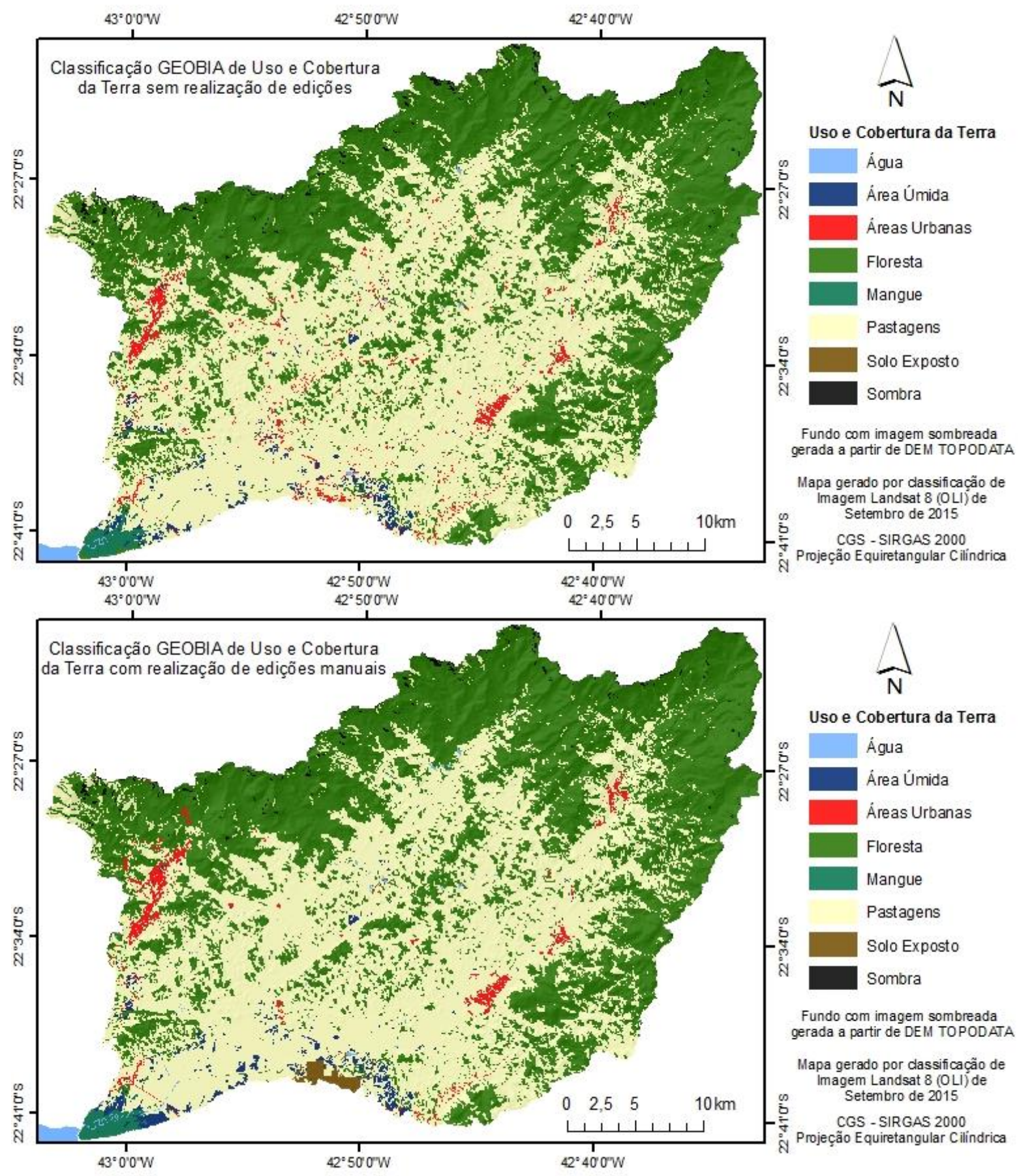




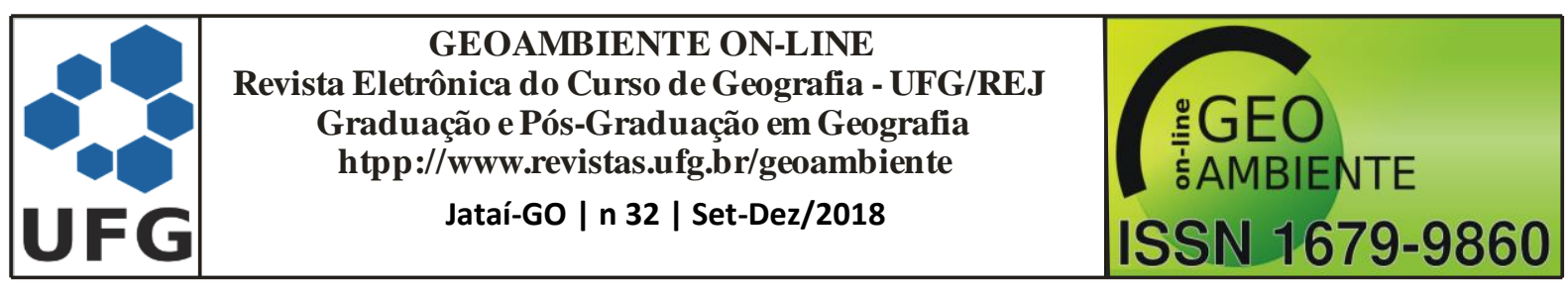

Quadro 1: Edições realizadas no mapa de Uso e Cobertura da Terra da bacia dos rios Macacu e Guapiaçu para o ano de 2015

\begin{tabular}{|c|c|c|c|c|}
\hline \multicolumn{5}{|c|}{ Classificação de Uso e Cobertura da Terra } \\
\hline Área Não Editada $\left(\mathbf{k m}^{2}\right)$ & $\%$ & $\begin{array}{c}\text { Área Editada } \\
\left(\mathbf{k m}^{2}\right)\end{array}$ & $\%$ & $\begin{array}{c}\text { Área Total } \\
\left(\mathbf{k m}^{2}\right)\end{array}$ \\
\hline $1.233,36$ & 97,35 & 33,53 & 2,65 & $1.266,89$ \\
\hline Edições Efetuadas & $\begin{array}{l}\text { Área } \\
\left(\mathbf{k m}^{2}\right)\end{array}$ & $\begin{array}{c}\% \text { das áreas } \\
\text { totais editadas }\end{array}$ & $\begin{array}{r}\% \text { das } \\
\text { m }\end{array}$ & $\begin{array}{l}\text { áreas totais do } \\
\text { peamento }\end{array}$ \\
\hline Editado de Áreas Úmida para Água & 0,01 & 0,03 & & 0,00 \\
\hline Editado de Áreas Úmida para Pastagens & 0,81 & 2,41 & & 0,06 \\
\hline Editado de Áreas Urbanas para Água & 0,02 & 0,07 & & 0,00 \\
\hline Editado de Áreas Urbanas para Área Úmida & 0,31 & 0,93 & & 0,02 \\
\hline Editado de Áreas Urbanas para Floresta & 0,01 & 0,02 & & 0,00 \\
\hline Editado de Áreas Urbanas para Pastagens & 7,18 & 21,42 & & 0,57 \\
\hline Editado de Áreas Urbanas para Solo Exposto & 1,91 & 5,69 & & 0,15 \\
\hline Editado de Floresta para Agua & 0,40 & 1,19 & & 0,03 \\
\hline Editado de Floresta para Área Úmida & 0,06 & 0,18 & & 0,00 \\
\hline Editado de Floresta para Áreas Urbanas & 0,01 & 0,02 & & 0,00 \\
\hline Editado de Floresta para Mangue & 0,99 & 2,95 & & 0,08 \\
\hline Editado de Floresta para Pastagens & 0,21 & 0,62 & & 0,02 \\
\hline Editado de Mangue para Agua & 0,33 & 0,98 & & 0,03 \\
\hline Editado de Mangue para Área Úmida & 0,37 & 1,10 & & 0,03 \\
\hline Editado de Mangue para Floresta & 0,11 & 0,33 & & 0,01 \\
\hline Editado de Pastagens para Agua & 0,61 & 1,82 & & 0,05 \\
\hline Editado de Pastagens para Área Úmida & 2,12 & 6,32 & & 0,17 \\
\hline Editado de Pastagens para Áreas Urbanas & 3,56 & 10,61 & & 0,28 \\
\hline Editado de Pastagens para Floresta & 10,59 & 31,60 & & 0,84 \\
\hline Editado de Pastagens para Solo Exposto & 3,94 & 11,74 & & 0,31 \\
\hline Total de Edições & 33,53 & 100 & & 2,65 \\
\hline
\end{tabular}

A presença da classe "Pastagens" em todas as principais alterações realizadas pelas edições, justifica-se por ser a classe predominante nas bacias (quadro 2) e ainda, pelo critério de classificação adotado para classe "Pastagem em Colinas", que foi definida a partir da exclusão dos objetos que não se adequaram aos modelos definidos para todas as demais classes 


\begin{tabular}{|c|c|c|}
\hline & $\begin{array}{c}\text { GEOAMBIENTE ON-LINE } \\
\text { Revista Eletrônica do Curso de Geografia - UFG/REJ } \\
\text { Graduação e Pós-Graduação em Geografia } \\
\text { htpp://www.revistas.ufg.br/geoambiente } \\
\text { Jataí-Go | n } 32 \text { | Set-Dez/2018 }\end{array}$ & $\begin{array}{c}\text { :GEO } \\
\text { G. AMBIENTE } \\
\text { G }\end{array}$ \\
\hline
\end{tabular}

temáticas (Not All). Ressaltando que estas edições somam valores inferiores a $2 \%$ da área total das bacias, que são valores relativamente baixos.

Quadro 2: Total em Área e Percentual de Uso e Cobertura da Terra da bacia dos rios Macacu e Guapiaçu para o ano de 2015

\begin{tabular}{|l|r|r|}
\hline \multicolumn{1}{|c|}{ Classe de Uso e Cobertura da Terra } & Área $\left(\mathbf{k m}^{2}\right)$ & \multicolumn{2}{c|}{$\%$} \\
\hline Água & 2,50 & 0,20 \\
\hline Área Úmida & 15,01 & 1,18 \\
\hline Áreas Urbanas & 15,90 & 1,25 \\
\hline Floresta & 584,47 & 46,13 \\
\hline Mangue & 7,30 & 0,58 \\
\hline Pastagens & 631,80 & 49,87 \\
\hline Solo Exposto & 5,85 & 0,46 \\
\hline Sombra & 4,07 & 0,32 \\
\hline Total & 1266,8867 & 100,00 \\
\hline
\end{tabular}

Pode-se observar ainda que as áreas editadas se distribuem ao longo das bacias de forma relativamente equitativa, salvo a área do COMPERJ, localizada na porção sul da área de interesse (figuras 2 e 5). Este recorte concentrou quase que todas as edições de pastagens para solo exposto, que representou 3,94\% das edições efetuadas em toda área $\left(11,74 \mathrm{~km}^{2}\right)$.

É importante ressaltar que a classe "Florestas", que foi a segunda mais representativa nas bacias (quadro 2), com uma área total de $584,47 \mathrm{~km}^{2}(46,13 \%)$ passou por poucas edições, tendo sido inclusive um pouco subestimada, já que ocorreu um pequeno acréscimo de área na medida em que $10,59 \mathrm{~km}^{2}$ previamente classificada como pastagem, foram editadas para floresta. Podemos dizer que os modelos escolhidos para esta classe se adequaram muito bem para a classificação das Florestas.

Quanto a distribuição do uso e cobertura da terra, podemos observar (figura 9) que a cobertura de florestas se distribui principalmente ao longo, e de maneira contínua, da escarpa da Serra do Mar e dos Patamares residuais. Também é possível perceber a presença de alguns fragmentos nos topos de morros e colinas existentes na porção central das bacias.

Os mangues e as áreas úmidas aparecem principalmente na porção jusante das bacias, justamente na área de menor declividade e de proximidade à foz dos rios Macacu e Guapiaçu. As principais áreas urbanas são representadas pelos núcleos de Guapimirim, Papucaia (no 


\begin{tabular}{|c|c|c|}
\hline & $\begin{array}{c}\text { GEOAMBIENTE ON-LINE } \\
\text { Revista Eletrônica do Curso de Geografia - UFG/REJ } \\
\text { Graduação e Pós-Graduação em Geografia } \\
\text { htpp://www.revistas.ufg.br/geoambiente } \\
\text { Jataí-Go | n } 32 \text { | Set-Dez/2018 }\end{array}$ & $\begin{array}{c}\text { :GEO } \\
\text { G. AMBIENTE } \\
\text { G }\end{array}$ \\
\hline
\end{tabular}

município de cachoeiras de Macacu) e Cachoeiras de Macacu, aparecendo muito pouco em outros espaços.

Os resultados da validação apontam para $85,36 \%$ de acerto no processo de classificação do uso e cobertura da terra nas bacias dos rios Macacu e Guapiaçu. É importante ainda salientar que os erros foram muito maiores para as classes de uso da terra (áreas urbanas, solo exposto e pastagens), com o total de 69 amostras $(23,39 \%)$. A classe de uso da terra mais representativa deste erro total foram as pastagens, que alcançaram 74,17\% de acerto. Já as áreas urbanas, dentre os usos da terra, alcançaram os melhores resultados, com o nível de acerto superando os $87 \%$ (quadro 3).

Quadro 3: Resultados da validação da classificação de uso e cobertura da terra das bacias dos rios Macacu e Guapiaçu

\begin{tabular}{|c|c|c|c|c|c|c|c|}
\hline & & $\begin{array}{c}\text { Objetos } \\
\text { selecionados para } \\
\text { validação }(\mathbf{2 0 \%})\end{array}$ & $\begin{array}{c}\text { Total de } \\
\text { Objetos } \\
\text { por Classe }\end{array}$ & $\begin{array}{c}\text { Total de } \\
\text { Erros }\end{array}$ & $\begin{array}{c}\% \text { de } \\
\text { Erros }\end{array}$ & $\begin{array}{l}\text { Total de } \\
\text { Acertos }\end{array}$ & $\begin{array}{c}\% \text { de } \\
\text { Acertos }\end{array}$ \\
\hline \multirow{11}{*}{ 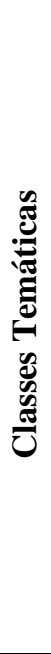 } & Água & 23 & 114 & 0 & 0,00 & 23 & 100,00 \\
\hline & Áreas Úmidas & 59 & 294 & 4 & 6,78 & 55 & 93,22 \\
\hline & Áreas Urbanas & 49 & 243 & 6 & 12,24 & 43 & 87,76 \\
\hline & Solo Exposto & 6 & 26 & 1 & 16,67 & 5 & 83,33 \\
\hline & Sombra & 28 & 140 & 3 & 10,71 & 25 & 89,29 \\
\hline & Florestas & 267 & 1335 & 23 & 8,61 & 244 & 91,39 \\
\hline & Mangues & 4 & 17 & 0 & 0,00 & 4 & 100,00 \\
\hline & Pastagens & 240 & 1198 & 62 & 25,83 & 178 & 74,17 \\
\hline & Total & 676 & 3367 & 99 & 14,64 & 577 & 85,36 \\
\hline & Usos da Terra & 295 & 1467 & 69 & 23,39 & 226 & 76,61 \\
\hline & $\begin{array}{l}\text { Coberturas } \\
\text { Naturais }\end{array}$ & 353 & 1760 & 27 & 7,65 & 326 & 92,35 \\
\hline
\end{tabular}

*Usos da Terra= Áreas Urbanas, Solo Exposto e Pastagens. Coberturas Naturais = Água, Áreas Úmidas, Floresta e Mangues.

Para as coberturas naturais (água, áreas úmidas, floresta e mangues), os resultados foram muito além das expectativas, ultrapassando o valor de $92 \%$ de acertos. As classes de água e mangue alcançaram os $100 \%$ de acertos, enquanto as de florestas ultrapassaram os valores de $91 \%$ de acertos. Além disso, tivemos para a classes de áreas úmidas, um erro inferior a $7 \%$, ou seja, mais que $93 \%$ de acerto. 


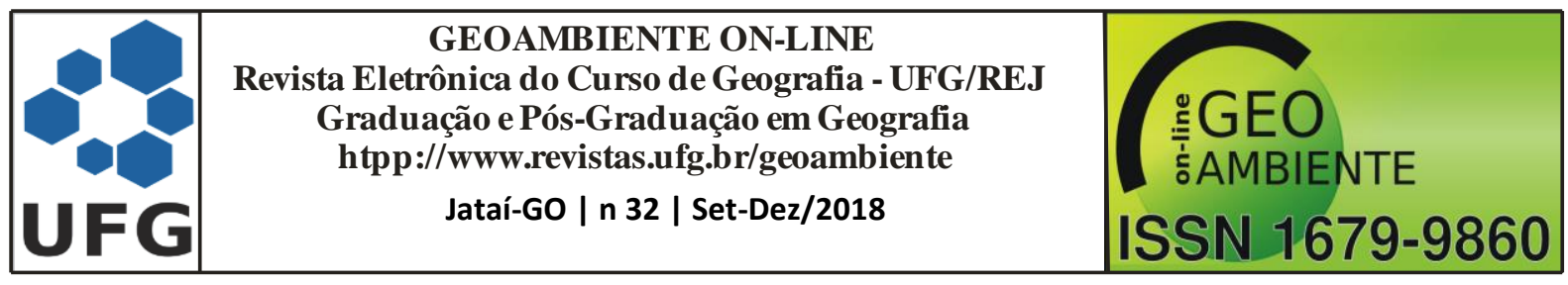

As áreas de sombra, que não foram consideradas uso da terra, tampouco cobertura natural, alcançaram 89,29\% de acertos, tendo sido um resultado muito satisfatório. Num futuro esforço de edição, para a posterior utilização do mapa de uso e cobertura da terra para diversas análises, a classe de sombras poderá ser incorporada a classe de florestas, uma vez que sua presença fora quase que integralmente detectada em áreas de floresta contínua, presentes principalmente no parque estadual de Três Picos.

Por mais que os resultados encontrados com a validação apontem um nível de acerto considerado satisfatório, resultando numa boa confiabilidade do mapa de uso e cobertura da terra das bacias dos rios Macacu e Guapiaçu, podemos apontar fatores de limitação do processo que talvez, hipoteticamente, pudessem elevar ainda mais a qualidade do produto gerado. Destes, podemos elencar: o problema da escala; o problema do centroide; o problema da data; a subjetividade da interpretação; e a caracterização do erro.

O problema da escala justifica-se pelo fato de que as imagens exibidas no Google Earth possuem um nível de detalhamento muito superior ao das imagens geradas pelo sensor OLI, transportado pelo satélite Landsat. Esta diferença implica dizer que alguns possíveis "erros" podem estar relacionados a objetos que não podem ser observados na escala 1:100.000, que é a escala pretendida para as análises existentes neste trabalho. Além disso, deve-se levar em consideração a simplificação na forma dos objetos quando os mesmos são representados em uma escala cartográfica menor.

O problema do centroide (figura 10), que é o centro geométrico de um polígono, ocorre quando o mesmo não está localizado no interior do polígono que representa o objeto a ser validado. Este caso não ocorreu com frequência nas análises efetuadas neste trabalho, mas se associado ao problema de escala, pode ser também considerado relevante para as investigações já que em algumas situações pode aumentar o erro de mapeamento equivocadamente.

O problema da data refere-se as diferenças nas datas da imagem, que pode ser um fator significante, principalmente em áreas de grande dinamismo, como o caso das bacias dos rios Macacu e Guapiaçu. Na área de estudos, foram encontradas imagens de diferentes datas, muitas datas dos anos de 2010, 2014 e até algumas anteriores a 2005. Estas diferenças podem tornar a estimativa do erro superior ao que de fato existe na análise de validação.

A subjetividade da interpretação pode também aumentar a imprecisão da validação, tornando os erros ainda maiores, caso a verificação das amostras seja observada de maneira 


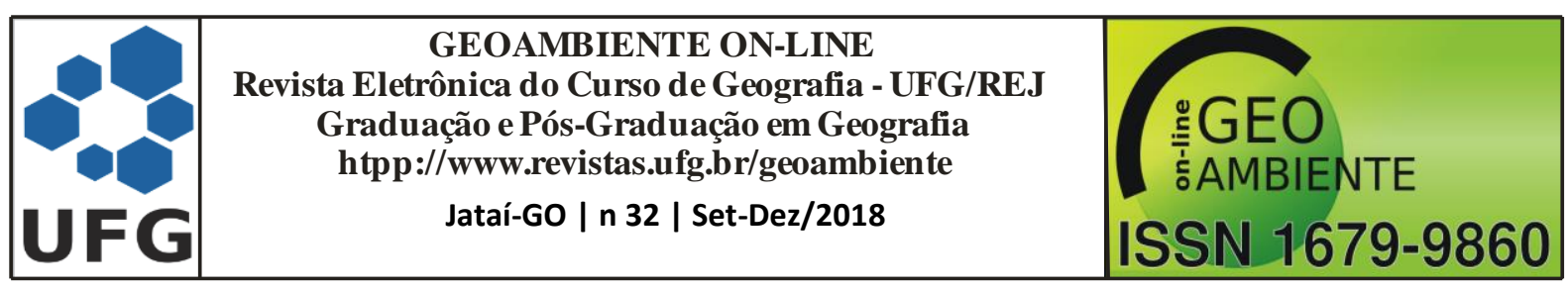

rigorosa, tal como foi efetuada neste trabalho. Em muitas situações, como a observada na figura 11, podemos perceber áreas que foram apontadas pelo mapeamento como "Floresta", e consideradas como Pastagens na validação, sugerem um rigor na interpretação, já que em alguns casos podemos perceber a formação de coberturas que poderiam estar na transição entre as duas classes (ex.: capoeiras).

Figura 10. O problema do Centroide

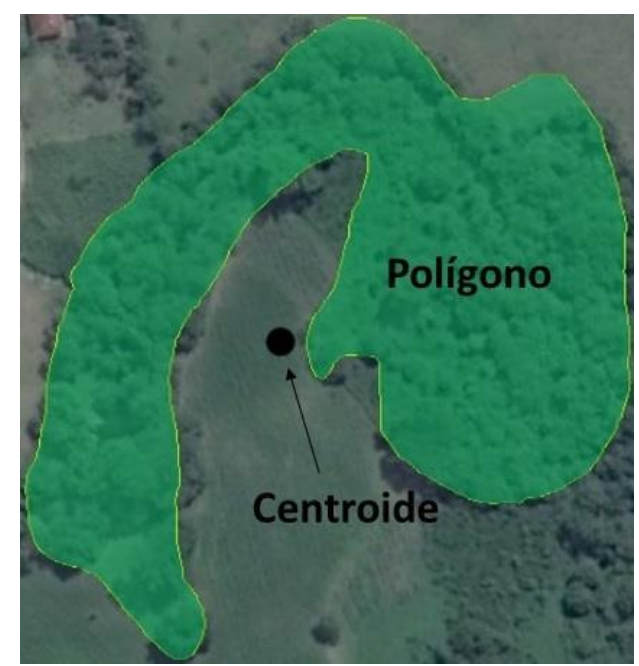

Figura 11. Subjetividade na interpretação. Floresta ou Pastagem?

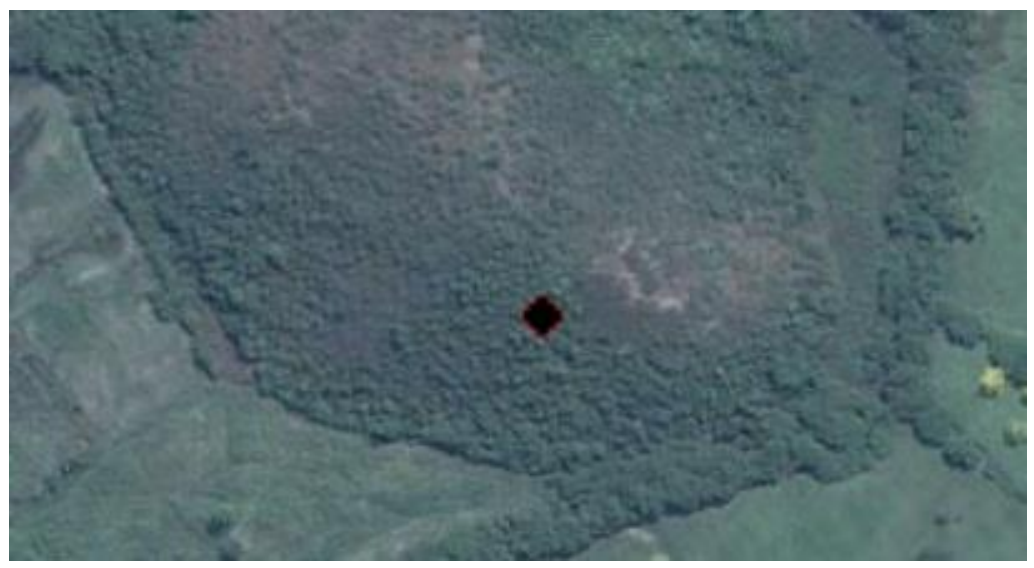

Alguns dos erros foram facilmente caracterizados, principalmente quando oriundos de confusões entre classes muito distintas, como por exemplo a classificação de áreas de Florestas (como observado no Google Earth) como áreas de Pastagens. Alguns outros erros, no entanto, poderiam ser considerados menos importantes, na medida em que podem ser causados por 


\begin{tabular}{|c|c|c|}
\hline & $\begin{array}{c}\text { GEOAMBIENTE ON-LINE } \\
\text { Revista Eletrônica do Curso de Geografia - UFG/REJ } \\
\text { Graduação e Pós-Graduação em Geografia } \\
\text { htpp://www.revistas.ufg.br/geoambiente } \\
\text { Jataí-Go | n } 32 \text { | Set-Dez/2018 }\end{array}$ & $\begin{array}{c}\text { :GEO } \\
\text { G. AMBIENTE } \\
\text { G }\end{array}$ \\
\hline
\end{tabular}

proximidades semânticas das classes observadas, tais como confusões entre áreas de pastagem com solo exposto, ou de área urbanas com solo exposto. Desta maneira, podemos afirmar que alguns erros podem ser caracterizados como menores, admissíveis, o que resulta no aumento da confiabilidade do dado.

No processo de validação, realizado a partir das imagens disponibilizadas pelo Google Earth, observou-se ainda a existência de uma classe temática não percebida no momento de interpretação da imagem OLI (Landsat 8), que foram os afloramentos rochosos. A dificuldade de observação desta classe deve-se a forte declividade das superfícies onde se encontram associado a pouca representatividade numérica e de área destes objetos. Estas áreas foram então generalizadas semanticamente, e desconsideradas no processo de validação do mapa final de uso e cobertura da terra.

\section{CONSIDERAÇÕES FINAIS}

A elaboração de métodos de interpretação do espaço geográfico de forma precisa e atualizada configura-se como fundamental para compreensão das mudanças da paisagem, sobretudo em áreas de grande dinamismo, tal como a região do Leste Fluminense, onde estão inseridas as bacias dos rios Macacu e Guapiaçu. A utilização de dados de sensoriamento remoto orbital apresenta-se neste contexto com relevante importância, já que permitem monitorar estas mudanças de forma holística, eficaz e com custo relativamente baixo.

A classificação de uso e cobertura da terra por modelagem do conhecimento e análise baseada em objetos deve ser precedida do esforço de correção atmosférica, já que a mesma melhora substancialmente a qualidade da imagem a ser interpretada, tendo impactos diretos no resultado final do mapeamento. A metodologia aplicada neste trabalho apresentou-se de maneira eficiente, uma vez que reduziu o esforço de edição, diminuindo no final a probabilidade de erros.

Os tipos de confusão encontrados na classificação, e corrigidos a partir do esforço de edição, ainda que tenham sido quantitativamente bem reduzidos, apontam para a necessidade de discutirmos mais a construção da árvore hierárquica de classificação, pois a construção de novos níveis, assim como a utilização de multiresoluções, podem minimizar ainda mais as confusões. 


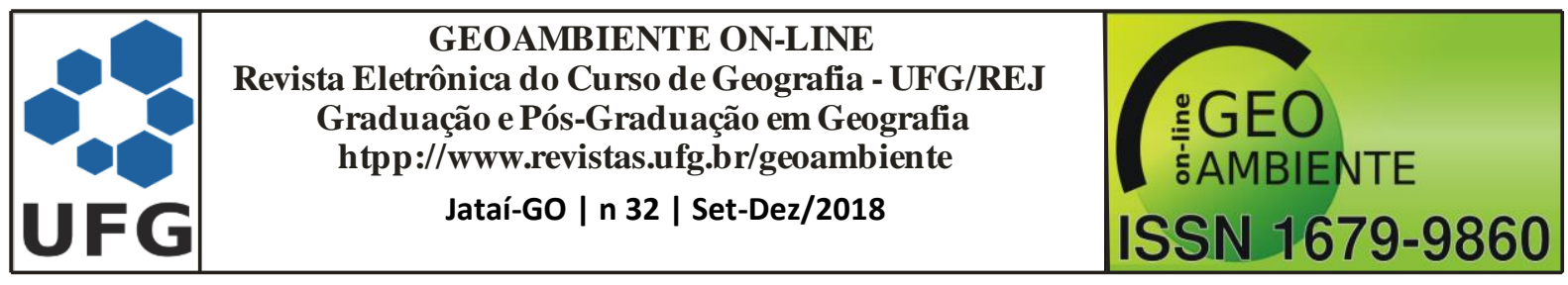

As áreas de pastagens são predominantes nas bacias dos rios Macacu e Guapiaçu, distribuindo-se principalmente nas porções central e sul da área de estudos. As áreas de Florestas, que também são muito representativas, distribuem majoritariamente, de maneira continua, nas escarpas da Serra do Mar e nos Maciços Alcalinos existentes nas bacias.

O método de validação, apesar de suas limitações, mostrou resultados satisfatórios, o que torna interessante a sua aplicação para iniciativas de mapeamento em outras áreas. $\mathrm{O}$ número de amostras, que representam valores superiores a $20 \%$ dos objetos existentes em cada classe temática do mapeamento, pode ser considerado suficiente para a proposta de validação e determinação da confiabilidade do dado.

\section{REFERÊNCIAS BIBLIOGRÁFICAS}

ANTUNES, M. A. H.; GLERIANI, J. M. \& DEBIASI, P. Atmospheric effects on vegetation indices of TM and ETM+ images from a tropical region using the $6 \mathrm{~S}$ model. In: Proceedings of the IEEE IGARSS 2012, Munich, pp. 6549-6552. 2012.

BLASCHKE, T. Object based image analysis for remote sensing. ISPRS Journal of Photogrammetry and Remote Sensing. Áustria, nº 65 (2010) 2-16.

CRUZ, C. B. M., ROSÁRIO, L. S., ABREU, M. B., ALMEIDA, P. M. M., VICENS, R.S.,CRONEMBERGUER, F. M. Classificação Orientada a Objetos na Geração do Mapa de Uso e Cobertura da Terra do estado do Rio de Janeiro. Anais XIV Simpósio Brasileiro de Sensoriamento Remoto, Natal, Brasil, 25-30 abril 2009, INPE, p. 7789-7796. 2009.

CRUZ, C.B.M., VICENS, R.S., SEABRA, V.S., REIS, R.B., FABER, O.A., RICHTER, M., ARNAUT, P.K.E., ARAUJO, M. Classificação orientada a objetos no mapeamento dos remanescentes da cobertura vegetal do bioma Mata Atlântica, na escala 1:250.000. XIII Simpósio Brasileiro de Sensoriamento Remoto, INPE, Florianópolis, Brasil. 2007.

DEFINIENS. The Principles of Definiens Cognition Network Technology. Disponível em: http://earthdefiniens.com/learn/technology. Acesso em 15/01/2010.

LANDIM, P.M.B. Análise Estatística de Dados Geológicos. Fundação Editora da UNESP, 2 a. Edição. 2003.

MONTEIRO, C. A. F. Os Geossistemas como elemento de integração na síntese geográfica e fator de promoção interdisciplinar na compreensão do ambiente. Florianópolis: Ed. da UFSC, 1996. 


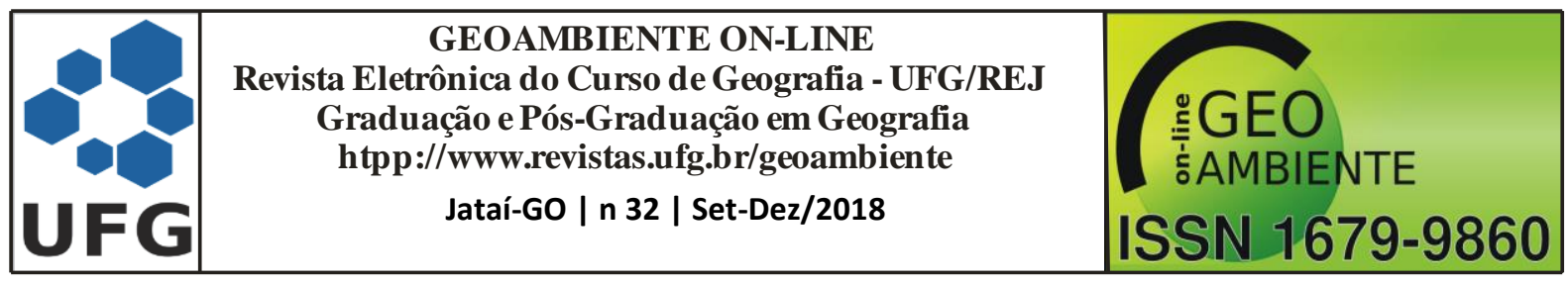

PIMENTA, M. L da F., COURA, P. H. F., CRUZ, C. B. M., \& LACERDA, E. R. Estudo das incertezas da definição de parâmetros no processo de correção atmosférica. In: XVI Simpósio Brasileiro de Sensoriamento Remoto (SBSR), Foz do Iguaçu, PR, 13 - 18 de abril 2013. Anais XVI SBSR. São José dos Campos: INPE, 2013. P. 1915 - 1922. CD-ROM, On-line. Disponível em: <http://marte2.sid.inpe.br/col/dpi.inpe.br/marte2/2013/05.29.00.18.08/doc/p1019.pdf> Acesso em 17 out. 2014.

RIÁBCHICOV, A. M. Estructura y Dinámica de La Esfera Geográfica: Su desarrollo natural y transformación por el hombre. Traducido del Ruso para Español por Isabel Alvarez Moran. Editorial MIR. Moscou. 1976.

SEABRA, V. S.; Uso de modelos digitais de elevação para mapeamento de variáveis morfométricas do relevo na bacia hidrográfica do rio São João. Revista Tamoios (Online), v. 2, p. 68-79, 2012.

SOARES, F. S., ALMEIDA, R. K., RUBIM, I. B., BARROS, R. S., CRUZ, C. B. M., MELLO, G. V., NETO, J. A. B. Análise comparativa da correção atmosférica de imagem do Landsat 8: o uso do $6 \mathrm{~S}$ e do ATCOR2. In: XVII Simpósio Brasileiro de Sensoriamento Remoto (SBSR), João Pessoa, XVII SBSR. São José dos Campos: INPE, 2015. Disponível em: <http:// www.dsr.inpe.br/sbsr2015/files/p0358.pdf> Acesso em 29 ago. 2015.

VALERIANO, M. M. Modelo digital de variáveis morfométricas com dados SRTM para o território nacional: o projeto TOPODATA. In: XII Simpósio Brasileiro de Sensoriamento Remoto, 2005, Goiânia, GO. Anais do XII Simpósio Brasileiro de Sensoriamento Remoto, p. 1-8. 2005.

ZHA, Y., GAO J., and NI S. Use of normalized difference built-up index in automatically mapping urban areas from TM imagery. International Journal of Remote Sensing, 24(3):583-594. 2003. 